\title{
IMPLEMENTASI KEBIJAKAN TABUNG GAS ELPIJI 3KG DI KECAMATAN TONDANO SELATAN
}

\author{
${ }^{1}$ Miriam Wullur, ${ }^{2}$ Jeane Mantiri \\ Universitas Negeri Manado \\ Imariamwullur@unima.ac.id, ${ }^{2}$ jeanelitha@unima.ac.id
}

\begin{abstract}
Abstrak
Penelitian ini bertujuan untuk mengetahui bagaimana Implementasi Kebijakan Tabung Gas Elpiji 3 kg di Kecamatan Tondano Selatan. Penelitian ini bertempat di Kecamatan Tondano Selatan, Menggunakan Metode penelitian kualitatif deskriptif, dimana peneliti menggambarkan dan menjelaskan situasi dan kondisi yang terjadi, setelah peneliti melakukan observasi dan wawancara. Hasil yang didapatkan adalah menyimpulkan bahwa implementasi kebijakan penyediaan dan pendistribusian Liquefied Petroleum Gas $3 \mathrm{~kg}$ di Kecamatan Tondano Selatan yang dianalisis dari aspek idealised policy, target groups, implementing organization dan environmental factor belum berjalan dengan baik.
\end{abstract}

\section{Kata Kunci: Tabung Gas, Tondano Selatan, Implementasi}

\section{PENDAHULUAN}

\subsection{Latar Belakang}

LPG merupakan bahan bakar berupa gas yang dicairkan (Liquified Petroleum Gasses) dan merupakan produk minyak bumi yang ramah lingkungan dan banyak digunakan oleh rumah tangga dan industri. Program konversi minyak tanah ke LPG yang diterapkan oleh pemerintah Indonesia sejak tahun 2007 kini telah menjangkau hampir seluruh kawasan Indonesia. Hal ini menyebabkan banyaknya permintaan masyarakat terhadap LPG, khususnya LPG $3 \mathrm{~kg}$. Salah satu produk LPG yang dikeluarkan oleh Pertamina ini paling banyak digunakan masyarakat karena praktis dan memiliki harga yang paling murah diantara tabung LPG lainnya. Kelancaran distribusi LPG $3 \quad \mathrm{~kg}$ kepada masyarakat sangat bergantung pada beberapa instansi. Distribusi LPG $3 \mathrm{~kg}$ dimulai dari PT Pertamina sebagai perusahaan minyak dan gas bumi nasional. Pengisian tabung gas LPG dilakukan di Stasiun Pengisian dan Pengangkutan Bulk Elpiji (SPPBE) yang tersebar di seluruh Indonesia.
Selanjutnya agen LPG $3 \mathrm{~kg}$ sebagai perusahaan swasta rekanan PT Pertamina akan mendistribusikan LPG ke pangkalan dan diteruskan kepada masyarakat. Sistem distribusi LPG $3 \mathrm{~kg}$ yang diterapkan merupakan sistem distribusi tertutup. Penerapan distribusi tertutup ini membuat pasokan LPG untuk setiap masyarakat yang dijatahkan oleh pemerintah sebanyak 3 tabung LPG per bulan lebih terjamin

Liquefied Petroleum Gas 3 KG adalah salah satu komoditas sektor migas yang diproduksi oleh PT Pertamina (Persero) yang disubsidi penuh oleh pemerintah agar para konsumen minyak tanah dapat beralih ke LPG. Penggunaan elpiji sebagai pengganti minyak tanah, selain bisa mengurangi beban pengeluaran keluarga miskin juga bisa menekan subsidi BBM yang selama ini ditanggung APBN, selain itu pemakaian elpiji tidak menimbulkan polusi yang berlebihan. Program konversi ini sendiri muncul seiring kian menipisnya persediaan minyak tanah bagi para masyarakat ekonomi kelas menengah ke bawah, dimana diharapkan dengan adanya program tersebut dapat menggantikan kelangkaan mitan di masyarakat, sekaligus 
menekan pengeluaran rumah tangga. Pada tahun 2018 belanja subsidi LPG tabung $3 \mathrm{~kg}$ telah menjadi komponen terbesar dalam subsidi energi, yang mencapai Rp58,14 triliun, atau $37,87 \%$ dari total subsidi energi sebesar Rp 153,52 triliun atau meningkat 14,95 kali lipat dibanding realisasinya pada tahun 2008. Peningkatan realisasi tersebut diantaranya dipengaruhi oleh peningkatan volume konsumsi LPG tabung $3 \mathrm{~kg}$ yang telah mencapai Rp6,54 miliar kg pada tahun 2018, atau meningkat 11,9 kali lipat dibandingkan volume konsumsi tahun 2008.

$$
\text { Peningkatan volume konsumsi }
$$

tersebut setidaknya dipengaruhi oleh dua faktor, yaitu (i) perluasan wilayah program konversi mitan ke LPG tabung $3 \mathrm{~kg}$, dan (ii) pertumbuhan alami kebutuhan konsumsi masyarakat. Faktor lainnya yang mempengaruhi peningkatan kebutuhan belanja subsidi LPG yaitu tingkat harga LPG tabung 3 kg tidak pernah mengalami penyesuaian sejak 2008 sebesar Rp4.250,00. Dalam pelaksanaannya, masih dijumpai permasalahan, diantaranya yaitu (i) pendistribusiannya masih dilakukan secara terbuka, sehingga semua golongan masyarakat masih dapat mengkomsumsi; (ii) tingkat harga LPG tidak pernah disesuaikan sejak tahun 2008 (Rp4.250,00), yang berakibat sebagian konsumen yang awalnya menggunakan LPG nonsubsidi juga ikut berpindah mengkonsumsi LPG bersubsidi; dan (iii) golongan masyarakat mampu juga menikmati subsidi LPG $3 \mathrm{~kg}$, sehingga mendorong ketimpangan dalam masyarakat.

Pada pelaksanaan dilapangan menunjukkan bahwa kelangkaan elpiji ini sangat menggelisahkan masyarakat. Masyarakat mengeluhkan keterbatasan elpiji 3 kg sampai dengan saat ini. Kelangkaan ini pun terjadi di seluruh wilayah Indonesia. Karena kelangkaan tersebut, maka para masyarakat selaku konsumen sulit untuk mendapatkannya, ini dikarenakan banyak kalangan menggunakan gas elpiji tersebut untuk kebutuhan sehari-hari, bahkan berbagai kalangan mulai beralih ke minyak tanah ataupun kayu ,mulai dari ibu rumah tangga, pedagang, dan yang lainnya. Para pengecer pun sangat susah untuk mendapatkan stok gas elpiji berukuran $3 \mathrm{~kg}$ tersebut karena kurangnya pasokan. Pihak pertamina telah menyediakan pasokan gas elpiji berukuran tiga kilogram ini agar dapat memenuhi kebutuhan semua kalangan, tetapi nyatanya upaya tersebut belum berjalan dengan semestinya, kelangkaan gas elpiji $3 \mathrm{~kg}$ terjadi karena banyaknya pengecer dalam suatu daerah, dan pihak pertamina berupaya untuk mengatasi kelangkaan terhadap gas elpiji berukuran $3 \mathrm{~kg}$ ini, agar pasokkannya tidak terbatas, serta dapat tersedia seperti biasanya.

Kekosongan elpiji saat ini oleh berbagai kalangan dicurigai karena adanya disparitas harga yang cukup tinggi antara elpiji $3 \mathrm{~kg}$ dengan $12 \mathrm{~kg}$. Hal inilah yang memancing dilakukannya tindakan pengoplosan (over tabung), akibatnya tabung menjadi langka, adanya perbedaan HET (Harga Eceran Tertinggi) pangkalan sangat berpotensi larinya elpiji dari suatu daerah ke daerah lain. Kelangkaan gas elpiji bersubsidi ukuran 3 kilogram ( $\mathrm{kg}$ ) di banyak wilayah menunjukkan distribusi elpiji tidak dilakukan dengan baik dengan tata niaga yang lemah. Karena itu, perlu langkah yang cepat dari pemerintah agar kelangkaan tersebut tidak menambah beban masyakat bawah.

Asumsi awal yang terbangun sebagaimana yang berkembang di masyarakat bahwa penyebab kelangkaan, karena adanya kuota konsumsi elpiji yang jebol di berbagai daerah. Proses distribusi selama ini sangat rapuh dan mudah terjadi kebocoran karena sistem agenisasi yang longgar. Elpiji $3 \mathrm{~kg}$ sangat dibutuhkan masyarakat bawah, sebagai konsekuensi konversi perpindahan dari minyak tanah (kerosine). Kenaikan dan kelangkaan yang terjadi akan berimplikasi langsung terhadap struktur pengeluaran masyarakat. Selain digunakan konsumen rumah tangga elpiji $3 \mathrm{~kg}$ juga banyak digunakan para pedagang kecil maupun usaha kecil menengah. 
Sebab itu perlu usaha serius dalam menangani permasalahan kelangkaan ini, karena telah menyangkut pertumbuhan ekonomi bagi masyarakat lemah.

Permasalahan Elpiji $3 \mathrm{~kg}$ pada tataran implementasi ini tidak dapat dianggap sepeleh sebab berkaitan langsung dengan masyarakat umum dan menyentuh langsung tataran kehidupan masyarakat. Peraturan dengan Nomor 26 Thun 2009 tentang Penyediaan dan Pendistribusian Liquefied Petrolium Gas sebagai dasar kebijakan dalam implementasi penyediaan dan pendistribusiannya perlu untuk ditelaah secara ilmiah guna ditemukan akar penyebab permasalahan. Dalam kajian keilmuan manajemen administrasi publik, kebijakan dalam implementasi merupakan bagian dari siklus kebijakan publik [1].

\subsection{Rumusan Masalah}

Bertitik tolak dari latar belakang di atas, maka yang menjadi permasalahan dalam penelitian ini adalah:

Bagaimana Implementasi Kebijakan

Tabung Gas Elpiji 3 kg di Kecamatan

Tondano Selatan?

\subsection{Tujuan Penelitian}

Berdasarkan latar belakang dan rumusan masalah di atas, selanjutnya tujuuan penelitian sebagai berikut:

Untuk mengetahui bagaimana Implementasi Kebijakan Tabung Gas Elpiji 3 kg di Kecamatan Tondano Selatan.

\section{METODE PENELITIAN}

\subsection{Pendekatan dan Jenis Penelitian}

Pendekatan dan jenis penelitian yang digunakan dalam penelitian ini adalah penelitian kualitatif deskriptif, dimana peneliti menggambarkan dan menjelaskan situasi dan kondisi yang terjadi, setelah peneliti melakukan observasi dan wawancara. Metode penelitian kualitatif sebagai prosedur penelitian yang menghasilkan data deskriptif berupa kata-kata tertulis atau lisan dari orang-orang dan perilaku yang dapat diamati, penelitian kualitatif akan menghasilkan prosedur analisis yang tidak menggunakan prosedur analisis statistik atau cara kuantifikasi lainnya.

Penelitian deskriptif adalah penelitian yang berisi kutipan-kutipan data untuk memberi gambaran penyajian. Data penelitian bisa diperoleh dari naskah, wawancara, catatan, foto, dokumen pribadi dan dokumen resmi lainnya. Laporan penelitian dilakukan dengan menganalisis data, dengan pertanyaan dengan kata Tanya mengapa, alasan apa dan bagaimana terjadinya akan senantiasa dimanfaatkan oleh peneliti [2]

Lokasi Penelitian di Kecamatan Tondano Selatan

\subsection{Kehadiran Peneliti}

Dalam penelitian kualitatif, kehadiran peneliti bertindak sebagai instrumen sekaligus pengumpul data. Kehadiran peneliti mutlak diperlukan, karena disamping itu kehadiran peneliti juga sebagai pengumpul data. Sebagaimana satu ciri penelitian kualitatif dalam pengumpulan data dilakukan sendiri oleh peneliti. Sedangkan kehadiran peneliti dalam penelitian ini sebagai pengamat partisipan/berperanserta, artinya dalam proses pengumpulan data peneliti mengadakan pengamatan dan mendengarkan secermat mungkin sampai pada yang sekecil-kecilnya [3].

\subsection{Data dan Sumber Data}

Menurut sumber data yang digunakan dalam penelitian ini, data dibedakan menjadi dua macam yaitu:

\section{Data Primer \\ Data primer merupakan data yang} diambil dan diolah sendiri oleh peneliti atau data yang secara langsung dikumpulkan sendiri oleh perorangan atau suatu organisasi melalui objeknya.

2. Data Sekunder

Data sekunder merupakan data yang bukan dihasilkan dan dikumpulkan oleh peneliti melainkan diperoleh dalam bentuk 
yang sudah diolah mengenai gambaran umum perusahaan seperti sejarah perusahaan, visi misi, struktur organisasi, data penjualan.

\subsection{Teknik Pengumpulan Data}

Agar diperoleh data yang valid dalam penelitian ini perlu ditentukan teknik-teknik pengumpulan data yang sesuai. Dalam hal ini peneliti penggunakan metode sebagai berikut:

\section{Wawancara}

Wawancara merupakan proses untuk memperoleh data atau keterangan untuk mencapai tujuan penelitian yang dilakukan dengan melalui kegiatan komunikasi verbal berupa percakapan. Alat pengumpulan data disebut pedoman wawancara dan sumber datanya disebut informan. Metode wawancara yang digunakan adalah wawancara terstruktur.

\section{Dokumentasi}

Dokumentasi merupakan metode yang mencari data mengenai hal-hal atau variabel yang berupa catatan, transkip, buku, surat kabar, majalah, agenda dan sebagainya. Adapun dokumen yang dimaksud dalam penelitian ini adalah buku panduan, majalahmajalah, dan transkip yang behubungan mengenai peran.

\subsection{Teknik Analisis Data}

Menurut Lexy J. Moleong, analisis data adalah proses mengorganisasikan dan mengurutkan data kedalam pola, kategori dan satuan uraian dasar sehingga dapat ditemukan tema dan dapat dirumuskan [2]. Analisis data dalam penelitian kualitatif dilakukan sejak sebelum memasuki lapangan, selama di lapangan dan setelah selesai di lapangan. Analisis data dalam penelitian ini menggunakan metode model Miles dan dan Hubermen yaitu selama proses pengumpulan data dilakukan 3 kegiatan penting diantaranya reduksi data (data reduction), penyajian data (data display), verifikasi (verification). Berikut adalah gambar dari proses tersebut:

Gambar diatas adalah gambar dari analisis data menurut Miles dan Huberman yang dikutip oleh Lexy J. Moleong. Dari gambar tersebut kita dapat melihat bahwa proses penelitian ini dilakukan secara berulang terus-menerus dan saling berkaitan satu sama lain baik dari sebelum, saat di lapangan hingga selesainya penelitian

\section{Pengumpulan Data}

Mengoleksi atau mengumpulkan data. Dalam tahap ini peneliti hadir di dalam objek penelitian untuk melakukan observasi, wawancara (interview), mencatat semua data yang dibutuhkan dalam penelitian ini.

2. Reduksi Data

Data yang diperoleh dari lapangan jumlahnya cukup banyak, sehingga perlu dicatat secara teliti dan rinci. Semakin lama peneliti di lapangan, maka jumlah data yang didapat juga semakin banyak, kompleks dan rumit, untuk itu perlu dilakukan reduksi data. Reduksi data memiliki makna merangkum, memilih hal-hal yang pokok, memfokuskan pada hal-hal yang penting, dicari tema dan polanya. Reduksi data berlangsung selama proses pengambilan data itu berlangsung, pada tahap ini juga akan berlangsung kegiatan pengkodean, meringkas dan membuat partisi (bagian-bagian). Proses transformasi ini berlanjut terus sampai laporan akhir penelitian tersusun lengkap.

\section{Penyajian Data}

Setelah mereduksi data, langkah yang dilakukan peneliti adalah melakukan pneyajian data. Penyajian data dapat di artikan sekumpulan informasi yang tersusun yang memberi kemungkinan adanya penarikan kesimpulan dan pengambilan tindakan. Penyajian ini dilakukan dalam bentuk uraian singkat, bagan, hubungan antar kategori. Penyajian data bertujuan agar peneliti dapat memahami apa yang terjadi dalam merencanakan tindakan selanjutnya yang akan dilakukan.

\section{Verifikasi}

Langkah terakhir dalam pengumpulan data adalah verifikasi. Dari awal pendataan, peneliti mencari hubungan-hubungan yang berkaitan dengan. permasalahan yang ada, melakukan pencatatan hingga menarik kesimpulan. Kesimpulan awal masih bersifat 
sementara dan akan selalu mengalami perubahan selama proses pengumpulan data masih berlangsung akan tetapi bila kesimpulan yang dibuat didukung oleh data yang valid dan konsisten yang ditemukan di lapangan, maka kesimpulan tersebut merupakan kesimpulan yang kredibel.

\subsection{Tahap-Tahap Penelitian}

Tahap-tahap ini terdiri dari beberapa tahap, yaitu tahap pra lapangan, tahap pekerjaan, tahap analisis data dan tahap pelaporan:

\section{Tahap Pra Lapangan}

Pada tahap ini peneliti melakukan berbagai macam persiapan sebelum terjun ke dalam kegiatan penelitian. Diantaranya yaitu mengurus perizinan, yang merupakan salah satu hal yang tidak dapat diabaikan begitu saja. Karena hal ini melibatkan manusia kelatar belakang penelitian. Kegiatan pra lapangan lainnya yang harus diperhatikan ialah latar penelitian itu sendiri perlu dijajaki dan dinilai guna melibatkan sekaligus mengenal unsurunsur dan keadaan alam pada latar penelitian.

2. Tahap Pekerjaan Lapangan

Tahap ini dilakukan dengan cara mengumpulkan data-data yang berkaitan dengan fokus penelitian dari lokasi penelitian. Dalam proses pengumpulan data ini penulis menggunakan metode wawancara dan dokumentasi.

3. Tahap Analisis Data

Pada tahap ini penulis menyusun semua data yang terkumpul secara sistematis dan terperinci sehingga data tesebut mudah dipahami dan temuanya dapat diinformasikan kepada orang lain secara jelas.

4. Tahap Pelaporan

Tahap ini merupakan tahapan terakhir dari tahapan yang peneliti lakukan. Tahapan ini dilakukan dengan membuat laporan tertulis dari hasil penelitian yang telah dilakukan.

\subsection{Keabsahan Data}

Penelitian kualitatif secara intern merupakan fokus perhatian dengan beragam metode. Harus didasari bahwa penggunaan metode triangulasi mencerminkan upaya untuk memperoleh pemahaman yang mendalam mengenai suatu fenomena yang sedang dikaji. Triangulasi bukanlah alah atau strategi validasi, namun merupakan alternatif bagi validasi. Triangulasi adalah teknik pemeriksaan keabsahan data yang memanfaatkan sesuatu yang lain. Di luar data itu untuk keperluan pengecekan atau sebagai pembanding terhadap data itu. Teknik triangulasi yag paling banyak digunakan ialah pemeriksaan melalui sumber lainnya. Menurut Denzin sebagaimana di kutip oleh Lexy J. Moleong, membedakan tiga macam triangulasi sebagai tekenik pemeriksaan keabsahan data. Dalam penelitian ini, peneliti menggunakan bentuk triangulasi metode, triangulasi metode dapat dilakukan dengan melakukan pengecekan data dari berbagai macam teknik pengumpulan data. Misalnya dengan menggunakan teknik wawancara mendalam dan dokumentasi. Data dari ketiga teknik tersebut dibandingkan adakah konsistensi, jika berbeda dijadikan catatan dan dilakukan pengecekan selanjutnya mengapa data bisa berbeda.

\section{HASIL DAN PEMBAHASAN}

Peraturan Bersama Menteri Dalam Negeri dan Menteri ESDM Nomor 5 dan 7 Tahun 2011 tentang Pembinaan dan Pengawasan Pendistribusian Tertutup Liquefied Petrolium Gas Tertentu di Daerah, Perpres Nomor 104 Tahun 2007 tentang Penyediaan, Pendistribusian dan Penetapan Harga Liquefied Petroleum Gas Tabung $3 \mathrm{~kg}$. Kebijakan - Kebijakan yang berkaitan dengan penyaluran LPG dari Pusat sampai di Daerah menunjukkan bahwa Pemerintah melalui Kementerian ESDM menerapkan distribusi LPG $3 \mathrm{~kg}$ secara tertutup. Hal ini dilakukan untuk mengarahkan penyaluran LPG $3 \mathrm{~kg}$ agar lebih tepat sasaran. Kementerian ESDM dan Kementerian Sosial telah bekerja sama terkait pendataan dan pembagian kartu kepada masyarakat yang berhak menggunakan LPG 3 kg. Kebijakan operasional yang ada di 
kabupaten Minahasa Selatan berkaitan dengan penyaluran Liquefied Petroleum Gas $3 \mathrm{KG}$ yaitu dikeluarkannya Keputusan Bupati Minahasa Selatan tentang Tim Kerja Pengawasan dan Pendistribusian BBM Premium, Solar dan Liquefied Petroleum Gas 3 $\mathrm{kg}$ [4].

Program - program kerja yang ditetapkan guna mewujudkan penyaluran Liquefied Petroleum Gas 3 KG berjalan dengan baik yaitu pengawasan dan pengendalian pendistribusian gas Liquefied Petroleum Gas 3 $\mathrm{kg}$, melakukan rapat-rapat koordinasi dengan tim kerja yang melibatkan unsur pemerintah daerah dan stakeholder melakukan pengawasan terhadap HET di pangkalan Liquefied Petroleum Gas 3 kg, melakukan koordinasi dan konsultasi dengan PT. Pertamina terkait kuota tahun berjalan masing-masing agen Liquefied Petroleum Gas 3 kg. Program - program kerja yang belum dapat dilakukan guna mewujudkan penyaluran Liquefied Petroleum Gas 3 KG berjalan dengan baik yaitu pembagian wilayah penyaluran sampai saat ini belum dapat dilaksanakan oleh karena masing-masing agen memiliki wilayah penyaluran se kabupaten. Kendala yang dihadapi yang mengakibatkan program - program kerja belum dapat dilakukan guna mewujudkan penyaluran LPG 3 KG berjalan dengan baik yaitu kurangnya koordinasi pihak PT. Pertamina dengan pemerintah daerah.

Adapun yang menjadi sasaran utama penyaluran LPG $3 \mathrm{KG}$ (berdasarkan kebijakan) yaitu rumah tangga berpenghasilan rendah dan Usaha Mikro. Alasan mendasar dipilihnya mereka sebagai sasaran utama penyaluran Liquefied Petroleum Gas 3 KG (berdasarkan kebijakan) yaitu bahwa dalam rangka untuk menjamin penyediaan dan pengadaan bahan bakar di dalam negeri dan mengurangi subsidi bahan bakar minyak guna meringankan beban keuangan negara. Rumah tangga adalah konsumen yang mempunyai legalitas penduduk, menggunakan minyak tanah untuk memasak dalam lingkup rumah tangga dan tidak mempunyai kompor gas untuk dialihkan menggunakan LPG Tabung $3 \mathrm{Kg}$ termasuk tabung, kompor gas beserta peralatan lainnya [5]. Usaha mikro adalah konsumen dengan usaha produktif milik perorangan yang mempunyai legalitas penduduk, menggunakan minyak tanah untuk memasak dalam lingkup usaha mikro dan tidak mempunyai kompor gas untuk dialihkan menggunakan LPG Tabung 3 $\mathrm{Kg}$ termasuk tabung, kompor gas beserta peralatan lainnya [5].

Syarat/kriteria yang diatur oleh kebijakan sehubungan dengan sasaran utama penyaluran LPG $3 \mathrm{KG}$ yaitu dalam rangka penyediaan dan pendistribusian LPG tabung 3 $\mathrm{kg}$, Menteri menetapkan harga patokan dan harga jual eceran LPG tabung $3 \mathrm{~kg}$ untuk Rumah Tangga dan Usaha Mikro. Menteri menetapkan harga patokan LPG tabung $3 \mathrm{~kg}$ setelah mendapatkan pertimbangan Menteri Keuangan. Menteri menetapkan harga jual eceran LPG tabung $3 \mathrm{~kg}$ didasarkan pada hasil kesepakatan instansi terkait yang dikoordinasikan oleh Menteri Koordinator Bidang Perekonomian. Direktorat Jenderal berkoordinasi dengan Pemerintah Provinsi/Kabupaten/Kota melaksanakan pendataan rumah tangga dan usaha mikro Pengguna LPG Tertentu yang memenuhi kriteria : memiliki kartu tanda penduduk (KTP) atau Kartu Penduduk Musiman dan kartu keluarga (KK) pada wilayah yang di data; mempunyai penghasilan tidak lebih dari $\mathrm{Rp}$ 1.500.000,00 (satu juta lima ratus ribu rupiah) per bulan dengan dibuktikan melalui slip gaji atau pengeluaran tidak lebih dari $\mathrm{Rp}$ 1.500.000,00 (satu juta lima ratus ribu rupiah) per bulan atau dengan surat keterangan tidak mampu dari kelurahan atau desa setempat [6]

Kenyataan yang terjadi di Kecamatan Tondano Selatan (sesuai/tidak) sasaran utama penyaluran LPG $3 \mathrm{KG}$ yaitu penyaluran gas elpiji di Minahasa Selatan dapat dikatakan belum sesuai dengan harapan oleh karena penjualan gas LPG $3 \mathrm{~kg}$ bersubsidi ini juga masih dinikmati oleh rumah tangga berkemampuan. Yang menjadi penyebab (sesuai/tidak) sasaran utama penyaluran LPG 3 KG yaitu tidak adanya ketegasan PT. Pertamina dalam hal mengawasi langsung ke pangkalan / 
sub agen tentang penjualannya. Pada pelaksanaannya, pola hubungan kerja antara sasaran utama penyaluran LPG 3 KG dengan pelaksana kebijakan yaitu untuk mendukung pelaksanaan pendistribusian/penyaluran LPG 3 kg maka dibentuk Tim Koordinasi Pusat, Tim Koordinasi Provinsi dan Tim Koordinasi Kabupaten / Kota. Masingmasing Tim Koordinasi melakukan tugas dan fungsinya sejak dari perencanaan, pelaksanaan, sosialisasi, monitoring, koordinasi dan evaluasi. Adapun jumlah sasaran utama penyaluran LPG 3 KG di Kabupaten Minahasa Selatan yaitu berdasarkan pantauan, pengawasan dan monitoring oleh Tim Koordinasi Kabupaten maka rata-rata rumah tangga dan usaha mikro di Kabupaten Minahasa Selatan telah menggunakan LPG 3 $\mathrm{kg}$ [7].

Kenyataan dan kendala yang dihadapi oleh sasaran utama penyaluran LPG $3 \mathrm{KG}$ setelah kebijakan ini diperlakukan yaitu sering terjadi kekurangan / kelangkaan elpiji di masyarakat yang diakibatkan oleh karena pengiriman LPG melalui kapal laut sebagai sarana transportasi terkadang menghadapi badai gelombang akibat curah hujan tinggi yang mengakibatkan kapal terlambat tiba di daerah perairan Sulawesi Utara. Sementara itu perbedaan mendasar yang dirasakan oleh sasaran utama penyaluran LPG $3 \mathrm{KG}$ sebelum dan sesudah kebijakan ini diberlakukan yaitu pada umumnya masyarakat menerima atas kebijakan yang dibuat pemerintah sejak konversi dari minyak tanah ke Liquefied Petroleum Gas yang ternyata ramah lingkungan dan hemat.

$$
\text { Pada tataran implementing }
$$

organization, hierarki kelompok pelaksana penyaluran LPG $3 \mathrm{Kg}$ yaitu Pemerintah menunjuk kepada Badan Usaha yang memiliki izin niaga untuk melaksanakan penyediaan dan pendistribusian. Badan Usaha yang mendapat penugasan memiliki izin usaha niaga. Dan badan usaha tersebut adalah PT. Pertamina. Selanjutnya dari PT. Pertamina mendistribusikan kepada lembaga penyalur dan menyalurkan LPG $3 \mathrm{~kg}$ kepada Stasiun
Pengisian dan Pengangkutan Bulk Elpiji (SPPBE) dan Stasiun Pengisian Bulk Elpiji (SPBE). Dari SPBE gas elpiji diberikan kepada Penyalur (Agen) dan selanjutnya diserahkan kepada Sub Agen untuk diteruskan kepada Rumah Tangga dan Usaha Mikro.

Kendala yang dihadapi oleh masing masing kelompok pelaksana penyaluran LPG $3 \mathrm{Kg}$ yaitu Ketersediaan stok gas LPG $3 \mathrm{~kg}$ di SPBE kadang-kadang mengalami kekurangan oleh karena keterlambatan melalui angkutan laut sementara kebutuhan akan elpiji oleh rumah tangga dan usaha mikro terus meningkat. Sementara itu pola pertanggungjawaban kerja dari masing - masing kelompok pelaksana penyaluran LPG $3 \mathrm{Kg}$ yaitu berdasarkan ketentuan maka kelompok penyalur atau agen menyampaikan laporan realisasi penyaluran gas LPG $3 \mathrm{~kg}$ kepada PT. Pertamina dan kepada Pemerintah Daerah sebagai unsur pengawasan di daerah. Baik secara administrasi keuangan dan administrasi pengelolaan pendistribusian kepada rumah tangga dan usaha mikro maka kelompok penyalur / agen menyiapkan data realisasi penyaluran berdasarkan log book yang diisi oleh sub agen / pangkalan dimana log book tersebut mencantumkan transaksi penjualan kepada rumah tangga dan usaha mikro. Seterusnya maka lembaga negara yang diberikan kewenangan melakukan pemeriksaan I audit dalam hal ini Badan Pemeriksa Keuangan melakukan pemeriksaan kepada kelompok penyalur / agen.

Berkaitan dengan environmental factor, pada implementasi kebijakan pendistribusian LPG $3 \mathrm{~kg}$ terlihat lingkungan budaya masyarakat Minahasa Selatan yang mendukung penyaluran LPG $3 \mathrm{Kg}$ berjalan dengan baik dimana masyarakat Minahasa Selatan yang homogen namun berperilaku budaya yang santun pada umumnya. Pada penggunaannya dimana masyarakat menggunakan gas elpiji $3 \mathrm{~kg}$ ternyata praktis dan dinamis. Lingkungan budaya masyarakat Minahasa Selatan yang kurang mendukung penyaluran LPG $3 \mathrm{Kg}$ menunjukkan bahwa kenyataan di lapangan bahwa masyarakat yang kurang mendukung adalah mereka yang tidak / 
belum paham tentang efisiensi biaya menggunakan gas elpiji dibanding dengan menggunakan kayu bakar atau minyak tanah. Demikian pula dengan faktor ekonomi seperti masyarakat yang tidak berpenghasilan tetap sehingga ketika akan mengeluarkan biaya pembelian gas elpiji masyarakat tertentu masih cenderung menggunakan kayu bakar yang menurut masyarakat biaya untuk mendapat kayu bakar lebih murah.

\section{KESIMPULAN}

Dari hasil dan pembahasan yang ada maka, peneliti menyimpulkan bahwa implementasi kebijakan penyediaan dan pendistribusian Liquefied Petroleum Gas $3 \mathrm{~kg}$ di Kecamatan Tondano Selatan yang dianalisis dari aspek idealised policy, target groups, implementing organization dan environmental factor belum berjalan dengan baik. Keadaan ini disebabkan sebagai akibat pada Idealised policy kebijakan penyediaan dan penyaluran yang diimplementasikan ke dalam bentuk program Liquefied Petroleum Gas $3 \mathrm{~kg}$ pada level peraturan tingkat Peraturan Pemerintah dan Peraturan Menteri telah sesuai akan tetapi pada operasional di tingkat kabupaten Tim Kerja Pengawasan dan Penertiban program yang ditetapkan tidak berjalan dengan baik dalam hal kurangnya koordinasi pihak PT. Pertamina dengan Pemerintah Daerah dalam program pembahasan pembagian wilayah penyaluran sampai saat ini belum dapat dilaksanakan oleh karena masing-masing agen memiliki wilayah penyaluran se-kecamatan Tondano Selatan.

\section{DAFTAR PUSTAKA}

[1] Peraturan dengan Nomor 26 Thun 2009 tentang Penyediaan dan Pendistribusian Liquefied Petrolium Gas

[2] Moleong, Lexy J. $2013 . \quad$ Metode Penelitian Kualitatif. Edisi Revisi. Bandung : PT. Remaja Rosdakarya.
[3] Sugiyono. 2006. Metode Penelitian Kuantitatif Kualitatif dan R\&D. Bandung:

[4] Peraturan Bersama Menteri Dalam Negeri dan Menteri ESDM Nomor 5 dan 7 Tahun 2011 tentang Pembinaan dan Pengawasan Pendistribusian Tertutup Liquefied Petrolium Gas

[5] Permen ESDM No. 26 Tahun 2009

[6] UU No. 18 Tahun 2006 tentang APBN

[7] Agustino, Leo. 2008. Dasar-Dasar Kebijakan Publik. Bandung : Alfabeta. 